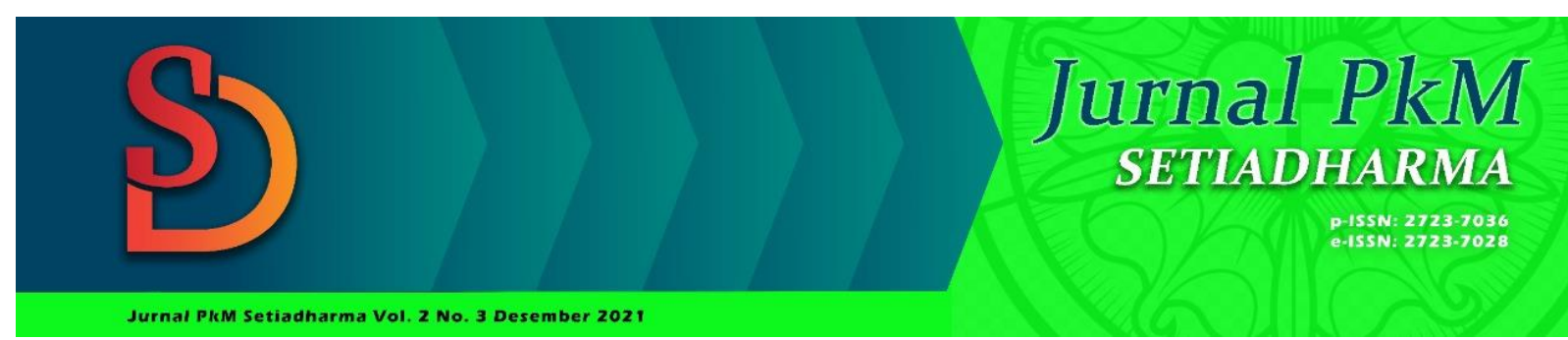

\title{
KONSELING PRANIKAH DALAM MEMPERSIAPKAN KELUARGA KRISTEN DI GEREJA KRISTEN SETIA INDONESIA (GKSI) “JEMAAT ISA ALMASIH” TAMAN MINI
}

\author{
Jonidius Illu, Joni Salman Gonto \\ Sekolah Tinggi Teologi Injili Arastamar (SETIA) Jakarta \\ joni.illu@gmail.com; jonisalmangonto@gmail.com
}

Diterima:
02-07-2021
Direview:
10-08-2021
18-12-2021
Direvisi:
22-11-2021
Diterbitkan:
31-12-2021
Keywords:
counseling,
premarital, family,
christian, GKSI
Kata Kunci:
konseling, pranikah,
keluarga, Kristen,
GKSI
Abstract
Some of the main issues that will be discussed in this paper include: 1)
the perception that premarital counseling is not important and a waste
of time; 2) premarital counseling is carried out only to fulfill the
requirements of marriage; 3) premarital counseling is considered an
unpleasant way because it talks about personal things. The aim of the
study is to show Christians that premarital counseling is important to
prepare for lifelong marriage. Starting a family needs to be well
prepared through premarital counseling so that each partner knows
who he is, what are his weaknesses and strengths in order to become a
family that grows in faith and lets go of the old pattern of life so that it
becomes a blessing.The method used is qualitative research with the
hope of giving the right perspective and attitude about the importance of
premarital counseling.

\section{Abstrak}

Beberapa isu pokok yang akan dibahas dalam tulisan ini antara lain: 1) adanya anggapan bahwa konseling pranikah tidak penting dan buangbuang waktu; 2) konseling pranikah dilakukan hanya sekadar memenuhi persyaratan perkawinan; 3) konseling pranikah dianggap cara yang kurang menyenangkan karena membicarakan hal-hal yang bersifat pribadi. Tujuan penelitian untuk menunjukkan kepada orang Kristen bahwa pentingnya konseling pranikah guna mempersiapkan perkawinan Kristen seumur hidup. Memulai sebuah keluarga Kristen perlu dipersiapkan dengan baik melalui konseling pranikah sehingga masing-masing pasangan mengenal siapa dirinya, apa yang menjadi kelemahan dan kelebihan supaya menjadi keluarga Kristen yang bertumbuh dalam iman dan melepaskan pola hidup lama sehingga menjadi berkat. Metode yang digunakan adalah penelitian kualitatif dengan harapan dapat memberi cara pandang dan bersikap yang benar tentang pentingnya konseling pranikah. 


\section{PENDAHULUAN}

Konseling pranikah belum dianggap sebagai hal yang penting oleh banyak kalangan termasuk oleh pasangan yang akan menikah, itu sebabnya banyak pasangan yang hendak menikah, mengharapkan agar konseling pranikah dipersingkat atau dipercepat waktu dan pembelajarannya. Selain itu, ada juga pasangan yang ketika ingin menikah, jika tahu bahwa salah satu persyaratan untuk mendapat pelayanan pemberkatan dan perkawinan kudus di suatu gereja adalah dengan mengikuti proses konseling pranikah maka kemudian memilih untuk mencari gereja lain yang mau melakukan pemberkatan nikah tanpa mengadakan konseling pranikah atau hanya sekadar diadakan percakapan singkat tentang kesiapan kedua belah pihak calon pengantin. Pendeta atau gereja yang menerima tanpa melakukan konseling pranikah pada umumnya terjadi karena ketidakmengertian tentang betapa pentingnya konseling pranikah itu sendiri. Prinsipnya jika pasangan ingin mengikuti konseling pranikah maka akan mengerti arti dari pernikahan dan rumah tangga Kristen sebab dalam proses konseling pranikah tersebut diajarkan materi-materi atau topik-topik yang berguna dalam menjalani kehidupan sebagai suami dan isteri ${ }^{1}$, sehingga mengerti tentang prinsip pernikahan dan rumah tangga Kristen berdasarkan Alkitab.

Jadi konseling pranikah sebagai suatu sarana yang diperuntukkan bagi pasangan yang akan memasuki rumah tangga Kristen agar mengetahui prinsip-prinsip dalam menjalankan kehidupan sebagai suami isteri sehingga dapat menjalankan sebuah rumah tangga Kristen yang berpedoman pada Alkitab sebagai dasar iman Kristen ${ }^{2}$ dan menjadikan rumah tangga Kristen sebagai tempat yang memancarkan kasih Kristus serta menjadi berkat bagi orang lain. Herman Ridderbosmenegaskan bahwa di dalam Tuhan, prinsip keterkaitan, saling bergantung dan saling melayani satu sama lain di dalam kasih, diaplikasikan dan dijalankan." 3 Jadi konseling pranikah bertujuan mempersiapkan setiap pasangan dalam membangun sebuah rumah tangga Kristen yang memuliakan Yesus Kristus artinya baik suami dan isteri menjalankan tugasnya berdasarkan Firman Tuhan sehingga tercermin sebagai sebuah rumah tangga Kristen yang mencerminkan gambar Allah.

Alkitab menjelaskan bahwa rumah tangga Kristen sebagai lembaga pertama yang didirikan Allah ${ }^{4}$ dengan tujuan mendemostrasikan kasih Allah dalam penatalayanan di dunia, namun tujuan tersebut tidak tercapai karena manusia telah gagal akibat ketidaktaatan dalam menjalankan perintah Allah dan menuruti keinginan Iblis, akibatnya relasi dengan Allah dan sesama termasuk dengan pasangan menjadi tidak harmonis. Darrell L. Hines ${ }^{5}$ menyatakan, "Salah satu alasan mengapa Iblis sangat berniat

\footnotetext{
${ }^{1}$ Morib AM., Pentingnya Pelayanan Konseling Pranikah, LOGON ZOES, Jurnal Teologi, Sosial dan Budaya, 2020. (AM, 2020)

${ }^{2}$ Jonathan A. Trisna, Two Become One - Membangun dan Mewujudkan Pernikahan Bahagia Sesuai Prinsip Alkitab, edisi ke-5. (Yogyakarta: ANDI, 2017), 2.

${ }^{3}$ Herman Ridderbos, Paulus Pemikiran Utama Theologinya, ed. Steve Hendra (Surabaya: Momentum, 2015), 322.

${ }^{4}$ Yakub B. Susabda berkata, "Allah yang berinisiatif untuk membentuk lembaga pernikahan, maka pastilah lembaga pernikahan mempunyai tujuan yang agung, lebih daripada sekadar manifestasi dari hukum alam. Jikalau Allah yang berinisiatif itu Allah yang sama yang juga mempunyai rencana keselamatan di dalam Yesus Kristus, maka pastilah tujuan pernikahan tidak pernah dilepaskan dari natur keselamatan Allah tersebut. Dengan kita mengakui bahwa pernikahan adalah inisiatif Allah, kita mengakui bahwa Allah mempunyai tujuan/rencana Allah itu hanya dapat dipahami jikalau "pernikahan" ditempatkan di dalam konteks keselamatan Allah dalam Kristus." Yakub B. Susabda, Pembinaan Keluarga Kristen (Bandung: Mitra Pustaka dan Pionir Jaya, 2011), 10.

${ }^{5}$ Darrell L. Hines, Pernikahan Kristen - Konflik \& Solusinya, ed. Rika Uli Napitupulu - Simorangkir (Jakarta: BPK. Gunung Mulia, 2018), 3.
} 
untuk menghancurkan pernikahan-pernikahan adalah karena setiap kali ia melihat pernikahan di mana dua orang benar-benar menjadi satu entitas, Iblis melihat sebuah refleksi dari natur Allah. Ia melihat kesatuan, harmoni, dan keutuhan - sungguh sebuah gambaran yang sepenuhnya dari kasih dan tujuan (yang ilahi). Itu sebabnya salah satu cara untuk mencegahnya adalah dengan menghadirkan Yesus Kristus dalam rumah tangga Kristen dengan cara setiap pasangan menerima Yesus Kristus sebagai Tuhan dan Juruselamat dan hidup dalam ketaatan terhadap Firman Allah sehingga tidak menjadi celah bagi Iblis untuk merusak rumah tangga Kristen. Jadi membangun rumah tangga Kristen perlu dipersiapkan melalui konseling pranikah sehingga prinsip kebenaran Firman Tuhan menjadi patokan agar Iblis tidak merusak rumah tangga Kristen dan baik suami isteri bertumbuh secara rohani dan secara relasi menjadi lebih sehat.

Dalam tulisan ini, penulis memaparkan pentingnya konseling pranikah bagi pasangan yang akan memasuki rumah tangga Kristen agar menyadari bahwa betapa pentingnya mempersiapkan perkawinan seumur hidup daripada pesta perkawinan sesaat sehingga dapat mempersiapkan diri dalam menghadapi berbagai tantangan dunia yang bisa merusak sebuah rumah tangga Kristen, dan masing-masing pasangan menjalankan fungsinya ${ }^{6}$ dengan maksimal serta memberikan dampak positif terhadap anak-anaknya, keluarga, gereja dan masyarakat.

GKSI “Jemaat Isa Almasih" Taman Mini, berdiri pada tanggal 15 Juni 2003, namun pelayanan konseling pranikah secara sistematis dan konsisten barulah ditetapkan dan dijalankan pada tahun 2012 yang bermula dari adanya suatu sesi diskusi tentang kehidupan rumah tangga Kristen dan bagaimana membangunnya agar berkenan kepada Allah. Melalui suatu Pendalaman Alkitab (PA) Keluarga di rumah salah satu rumah jemaat, dalam diskusi ditemukan bahwa konseling pranikah selama ini belum dilaksanakan secara konsisten karena konseling pranikah dianggap tidak penting, buang waktu dan bukanlah bagian utama dalam persiapan suatu perkawinan, karena jemaat beranggapan bahwa sebuah rumah tangga Kristen akan secara otomatis berjalan jika sudah menikah dan alasan lain bahwa pada zaman dahulu, orangtua juga tidak melewati konseling pranikah tetapi terlihat bahagia sampai maut memisahkan.

Banyak rumah tangga Kristen yang memiliki pemahaman bahwa setelah menikah akan secara otomatis berjalan sendiri sesuai dengan apa yang diharapkannya, akibatnya baik suami dan isteri tidak memahami apa artinya membentuk rumah tangga Kristen dan apa tujuannya serta bagaimana membangun sebuah rumah tangga Kristen yang sehat berdasarkan prinsip Firman Tuhan. ${ }^{7}$ Akhirnya hasil diskusi tersebut dibawa dalam rapat para pendeta, majelis dan anggota jemaat dan disepakati bahwa konseling pranikah sebagai salah satu pelayanan yang akan konsisten dilakukan untuk pasangan yang akan masuk dalam rumah tangga Kristen dan menjadi tanggung jawab hamba Tuhan (pendeta) untuk penatalayanan dan mempersiapkan materi konseling pranikah. Menurut Armand Barus, pendeta bertugas memberikan makanan rohani kepada sehingga jemaat menjadi serupa dengan Kristus. ${ }^{8}$ Itu sebabnya maka dimulai konseling pranikah pada tahun 2012 sampai saat ini dan menjadi syarat utama sebelum pelaksanaan pemberkatan perkawinan kudus atau peneguhan nikah. ${ }^{9}$

\footnotetext{
${ }^{6}$ Bagi isteri, perlu menyadari bahwa posisi suami sebagai pemimpin dan bagi suami berkewajiban untuk mengasihi. Ridderbos, Paulus Pemikiran Utama Theologinya.

${ }^{7}$ Evi Oktavia Manalu, Pengaruh Konseling Pranikah Terhadap Keutuhan Keluarga, Jurnal Teologi dan Pelayanan, vol. 6, 2020, https://sttintheos.ac.id/e-journal/index.php/antusias.

${ }^{8}$ Armand Barus, Spiritualitas Pastoral (Jakarta: Sekolah Tinggi Teologi Amanat Agung, 2019), 8-9.

${ }^{9}$ Perberkatan perkawinan kudus dan peneguhan nikah adalah dua jenis pelayanan yang berbeda. Disebut pemberkatan perkawinan kudus karena belum terjadi kehamilan dan dapat dilaksanakan di gereja dan disebut peneguhan nikah dalam kategori sudah hamil sebelum menikah atau sudah hidup
} 
Dalam menjalankan konseling pranikah bagi setiap pasangan yang akan menikah tidaklah mudah karena: a)seringkali tidak diikuti dengan serius, hal ini dapat dibuktikan ketika diberikan pertanyaan bersadarkan topik diskusi tidak dapat dilaksanakan atau dijawab; b) sangat sibuk sehingga tidak maksimal mengikuti konseling pranikah dan tidak sempat membaca materi konseling pranikah; c) konseling pranikah dianggap terlalu banyak topik dan waktu yang digunakan terlalu lama, sehingga seringkali diusulkan oleh pasangan yang mau menikah dan keluarga mampelai untuk dipersingkat dengan berbagai alasan, misalnya terlalu sibuk bekerja. Keadaan ini dapat dilewati dengan baik oleh karena baik dalam khotbah dan pendalaman Alkitab serta ada pembinaan iman yang dilakukan oleh gereja, terus-menerus diberikan pemahaman tentang pentingnya konseling pranikah. Seiring berjalannya waktu maka jemaat dapat mengerti dan bersedia mengikuti konseling pranikah dalam mempersiapkan rumah tangga Kristen dan konseling pranikah menjadi suatu kebutuhan dasar dalam mempersiapkan rumah tangga Kristen yang baru.

\section{METODE PELAKSANAAN}

Metode yang digunakan dalam penulisan Pengabdian kepada Masyarakat ( PkM) ini, yaitu kualitatif, dengan menemukan pendapat dari beberapa penulis dan hasil wawancara bagi pasangan yang akan menikah untuk menemukan informasi dalam menyelesaikan tulisan ini agar bermanfaat bagi pembaca.

Dalam PkM ini, penulis memberikan dua contoh pelaksanaan konseling pranikah, yaitu:

1. Waktu : 12 Januari $2020-1$ Agustus 2020

Tempat : GKSI “Jemaat Isa Almasih" Taman Mini

Alat yang digunakan : Alkitab dan Materi Pembinaan Konseling Pranikah

2. Waktu : 5 September $2020-7$ November 2020

Tempat : : GKSI "Jemaat Isa Almasih" Taman Mini

Alat yang digunakan : Alkitab dan Materi Pembinaan Konseling Pranikah

Dua contoh PkM di atas, dilaksanakan tatap muka dengan mengikuti protokol kesehatan. Setiap pertemuan yang dilaksanakan, cara yang dilakukan yaitu menjelaskan setiap materi kepada pasangan, kemudian dilanjutkan dengan diskusi serta memberikan pekerjaan rumah (PR) bagi setiap pasang. Tujuan memberikan pekerjaan rumah (PR) agar setiap pasangan berdoa, memikirkan dan menjawab sebagai bentuk pertanggungjawaban iman, misalnya tema ke empat tentang mengapa menikah dengan beberapa pertanyaan antara lain: a) Apa yang mendorong Anda memutuskan untuk menikah?; b) Menurut Anda, mengapa pasangan Anda memutuskan untuk menikah dengan Anda?; c) Sejauh mana Anda merasa siap untuk menikah? Apa bukti kesiapan Anda tersebut? Pertemuan selanjutnya dilakukan dengan cara yang sama sampai pada pertemuan terakhir dilaksanakan evaluasi dengan memberikan beberapa pertanyaan antara lain: a) menurut Anda, mengapa konseling pranikah ini penting untuk Anda?; b) Apakah konseling pranikah ini berguna bagi Anda? Jika ya jelaskan?; c) Sejauh mana Anda memahami selama Anda mengikuti konseling pranikah?; d) Topik bahasan manakah yang paling bermanfaat bagi Anda? Mengapa?

Metode ini dengan tujuan agar setiap pasangan dapat mempelajari setiap materi dengan merefleksikan setiap pertanyaan agar apa yang dipelajari dapat dimengerti dan

bersama sebagai suami isteri tanpa hubungan yang resmi atau sudah menikah dan terjadi perceraian namun ingin menikah lagi sehingga pelaksanaannya di rumah. 
menjawab setiap pertanyaan untuk membuktikan sejauh mana setiap pasangan dapat memahami setiap topik.

\section{HASIL DAN PEMBAHASAN}

Pada bagian ini penulis menjelaskan beberapa hal antara lain: pengertian konseling pranikah, pentingnya konseling pranikah, memahami setiap topik konseling pranikah, dan hasil konseling pranikah.

\section{A. Pengertian Konseling Pranikah}

Ada dua kata yang dihubungkan yaitu kata konseling dan pranikah. Konseling sendiri memiliki arti sebagai suatu cara atau teknik yang dilakukan oleh seorang yang memiliki profesi sebagai seorang konselor. Yakub B. Susabda ${ }^{10}$ mengatakan "Konseling merupakan pelayanan (melalui percakapan) yang membutuhkan kemampuan dan disiplin yang sangat tinggi. Disamping berbagai kemampuan yang harus dimiliki oleh konselor, konseling juga memerlukan strategi." Dalam hal ini seorang konselor yang memiliki keahlian atau keterampilan dalam menjalankan konseling secara bertanggungjawab ${ }^{11}$ dengan menggunakan teknik-teknik yang dipelajari secara akademik sehingga ia menunjukkan diri sebagai orang yang memiliki profesi sebagai konselor. ${ }^{12}$ Artinya tidak semua yang melakukan berperan dalam melakukan konseling disebut sebagai konselor, ia bisa menjalankan pastoral karena isinya memberikan nasihat-nasihat. Jadi konseling adalah pelayanan yang dilakukan oleh seseorang dengan memiliki ketrampilan dalam melakukan konseling, sedangkan pastoral karena isinya pemberian nasihat maka bisa dilakukan oleh setiap orang Kristen karena ia mengetahui isi Alkitab.

Pranikah adalah suatu bentuk persiapan yang dilakukan oleh hamba Tuhan untuk mempersiapkan pasangan yang akan masuk dalam rumah tangga Kristen. Jadi konseling pranikah adalah suatu kegiatan yang dilakukan oleh seorang konselor dalam mempersiapkan pasangan untuk masuk dalam sebuah rumah tangga Kristen yang dibangun berdasarkan prinsip iman Kristen agar beriman kepada Yesus Kristus dan memiliki karakter yang baik atau takut akan Tuhan.

\section{B. Pentingnya Konseling Pranikah}

Dalam pengamatan dan evaluasi selama melakukan konseling pranikah, maka penulis memperhatikan bahwa konseling konseling penting karena memiliki beberapa tujuan, antara lain: 1) mengarahkan kedua pasangan untuk memiliki pemikiran dan hati yang sama tentang betapa pentingnya memiliki satu iman di dalam Yesus Kristus dalam membangun sebuah rumah tangga Kristen yang bertanggung jawab. Hal ini menjadi dasar rumah tangga Kristen karena memiliki nilai kekal dan mengarahkan hidup pada tujuan hidup yang bersifat kekal. ${ }^{13}$ Ditambahkan oleh Clayton dan Charie King ${ }^{14}$ bahwa,

\footnotetext{
${ }^{10}$ Yakub B. Susabda, Menjadi Konselor Yang Profesional (Yogyakarta: ANDI, 2011), 53.

${ }^{11}$ Lihat Jonidius Illu, "Peran Gereja Dalam Pelayanan Pastoral Terhadap Pasangan Hamil Sebelum Menikah," Phronesis 3 No. 1 Ju (2020): 102.

${ }_{12}$ Yakub B. Susabda, Konseling Pastoral (Jakarta: BPK Gunung Mulia, 2014), 5-6.

${ }^{13}$ Stevri Indra Lumintang \& Danik Astuti Lumintang, Theologi Pernikahan Kristen Di Tengah Krisis (Jakarta: Ithl, 2016), 201-202.

${ }^{14}$ Clayton \& Charie King, 12 Pertanyaan Yang Harus Diajukan Sebelum Anda Menikah (Jakarta: Immanuel, 2013), xv.
} 
"sesudah pengenalan akan Kristus, sebuah pernikahan yang memuaskan dan keluarga yang penuh kasih adalah tujuan terbesar yang dapat kita cita-citakan di dalam hidup ini; 2) setiap pasangan mengetahui tentang siapa dirinya ${ }^{15}$, apa kelebihan dan kekurangannya sehingga membangun sebuah sistem hidup yang sehat dan yang terutama adalah hal-hal yang kurang dalam diri setiap pasangan yang perlu disadari dan memiliki strategi untuk membuang hal-hal yang tidak berkenan sebelum masuk dalam rumah tangga Kristen sehingga tidak merusak perkawinan Kristen atau dengan kata lain, setiap pribadi memiliki perubahan hidup. Hal ini ditegaskan Dale Mathis dan Susan Mathis bahwa, "salah satu sarana utama pernikahan Anda seharusnya untuk membentuk pola yang sehat untuk menaungi perbedaan sejak awal. Lebih baik menyadari sekarang bahwa Anda tidak memiliki kecakapan yang baik serta berusaha membentuk pola yang baik daripada menerapkan pola yang tidak sehat dalam pernikahan Anda dan melukai pasangan Anda16; 3) setiap pribadi memperlengkapi diri dengan hal-hal yang positif agar semakin sehat dan semakin utuh menjadi berkat. Hal ini ditegaskan oleh Yakub B. Susabda, "Setiap pasangan perlu waspada dan memperlengkapi diri dengan persiapan yang lebih baik. ${ }^{17}$

Jadi konseling pranikah penting karena mempersiapkan calon pasangan suami isteri untuk masuk dalam rumah tangga Kristen sehingga dalam menjalani kehidupan bersama mampu menghadapi situasi yang sulit, baik internal dan eksternal dan terutama yaitu rumah tangga Kristen yang dibangun atas dasar iman kepada Yesus Kristus dan memiliki kehidupan moral atau karakter yang berkenan kepada Allah, agar nama Yesus Kristus dimuliakan.

\section{Memahami Setiap Topik Konseling Pranikah}

Topik-topik yang menjadi materi diskusi bukan sekadar memenuhi persyaratan pertemuan, tetapi topik-topik tersebut langsung berkaitan dengan kehidupan rumah tangga Kristen. Topik-topik antara lain: 1) Iman setiap pasangan; 2) Jaminan keselamatan; 3) Alkitab sebagai pedoman rumah tangga Kristen; 4) Mengapa menikah; 5) Perkawinan Kristen; 6) Mengenal kepribadian diri dan pasangan; 7) Komunikasi dalam perkawinan; 8) Keuangan; 9) Kekudusan seksual; 10) Kesehatan; 11) Menghadapi konflik; 12) Perceraian; 13) Kehidupan keluarga dan rumah tangga; 14) Undang-undang perkawinan; 15) Janji perkawinan; 16) dan Evaluasi. Pemahaman ini juga dijelaskan dalam Psikologia: Jurnal Pemikiran dan Penelitian Psikologi (2016) bahwa, "Materi yang dianggap paing bermanfaat adalah keluarga asal pasangan (menggunakan teknik genogram dari terapi keluarga Bowenian), konflik, komunikasi, serta peran dan tanggung jawab suami atau isteri dalam rumah tangga."18

Topik-topik di atas, diuraikan atau dijelaskan kemudian para calon pengantin diberikan kesempatan untuk menjelaskan ulang atau menjawab pertanyaan-pertanyaan sesuai topik, misalnya topik ke-4 (mengapa menikah), dengan beberapa pertanyaan

${ }^{15}$ Konseling yang bijak menolong orang untuk menghadapi dirinya sendiri secara jujur. Hal ini menolong mereka untuk menatap mereka ke dalam satu-satunya cermin yang benar: Apa yang Allah lihat di dalam diri saya? Ini menolong orang untuk mengonfrontasi penderitaan: di manakah Allah menempatkan saya, dan bagaimana saya akan berespons? Kita umat manusia dengan sengit melawan upaya untuk melihat diri kita sebagaimana Allah melihat kita. Mematahkan perlawanan kita terhadap terang itu membuka pintu menuju kebaikan, keakraban, dan anugrahAllah. David Powlison, Mengatakan Kebenaran Dalam Kasih (Surabaya: Momentum, 2011).

16Dale Mathis \& Susan Mathis, Menuju Pernikahan Yang Sehat Dan Solid (Yogyakarta: ANDI, 2014), 116.

${ }^{17}$ Yakub B. Susabda, Konseling Pranikah (Bandung: Mitra Pustaka, 2005), 9.

${ }^{18}$ https://www.mendeley.com/catalogue/66b8b40d-49fc-30f4-8833-885b70d83d86 
antara lain: Apa yang mendorong Anda memutuskan untuk menikah?, menurut Anda, mengapa pasangan Anda memutuskan untuk menikah dengan Anda?, sejauh mana Anda merasa siap untuk menikah? Dan apa bukti kesiapan Anda tersebut?

Jadi topik-topik di atas, tidak sekadar dipelajari dan hanya terlewatkan oleh setiap pasangan, namun yang penting yaitu setiap pasangan memahami atau mengerti dan bisa diterapkan dalam membangun rumah tangga Kristen.

Untuk mengukur tingkat pemahaman setiap pasangan, pada pertemuan terakhir dilaksanakan evaluasi dengan memberikan beberapa pertanyaan antara lain: a) menurut Anda, mengapa konseling pranikah ini penting untuk Anda?; b) Apakah konseling pranikah ini berguna bagi Anda? Jika ya jelaskan?; c) Sejauh mana Anda memahami selama Anda mengikuti konseling pranikah?; d) Topik bahasan manakah yang paling bermanfaat bagi Anda? Mengapa?

\section{Hasil Konseling Pranikah}

Pada bagian pertemuan terakhir, setiap pasangan memberikan jawaban atas pertanyaan evaluasi guna menemukan hasil akhir. Pertanyaan evaluasi itu antara lain: 1) Menurut Anda, mengapa konseling pranikah ini penting untuk Anda?; 2) Apakah konseling pranikah ini berguna bagi Anda? Jika ya jelaskan?; 3) Sejauh mana Anda memahami tentang pernikahan dan rumah tangga Kristen selama Anda mengikuti konseling pranikah?; 4) Topik bahasan manakah yang paling bermanfaat bagi Anda? Mengapa?; 5) Apa perubahan hidup yang Anda inginkan atau harapkan?

Dua pasangan di bawah ini sama-sama memberikan jawaban bahwa konseling pranikah sangat penting karena dengan setiap materi yang diberikan dapat dimengerti dan menyadari bahwa ini berguna untuk kehidupan keluarga yang akan dibentuk, terutama setiap pasangan menyadari akan setiap kelemahan dan berkomitmen untuk meninggalkan agar tidak merusak rumah tangga Kristen yang akan dibentuk. Selain itu, hasil yang lain yaitu masing-masing pasangan menemukan kekuatan untuk mengembangkan diri dan saling mendorong satu dengan yang lain sehingga semakin setia dan mengalami pertumbuhan baik secara rohani dan jasmani (mental, karakter) guna menjadi berkat bagi pasangan lain.

Berikut dua pasangan yang berhasil mengikuti konseling pranikah dan menerima pemberkatan perkawinan kudus antara lain:

1. Mengikuti konseling pranikah dan kemudian menerima pemberkatan perkawinan kudus pada tanggal 1 Agustus 2020

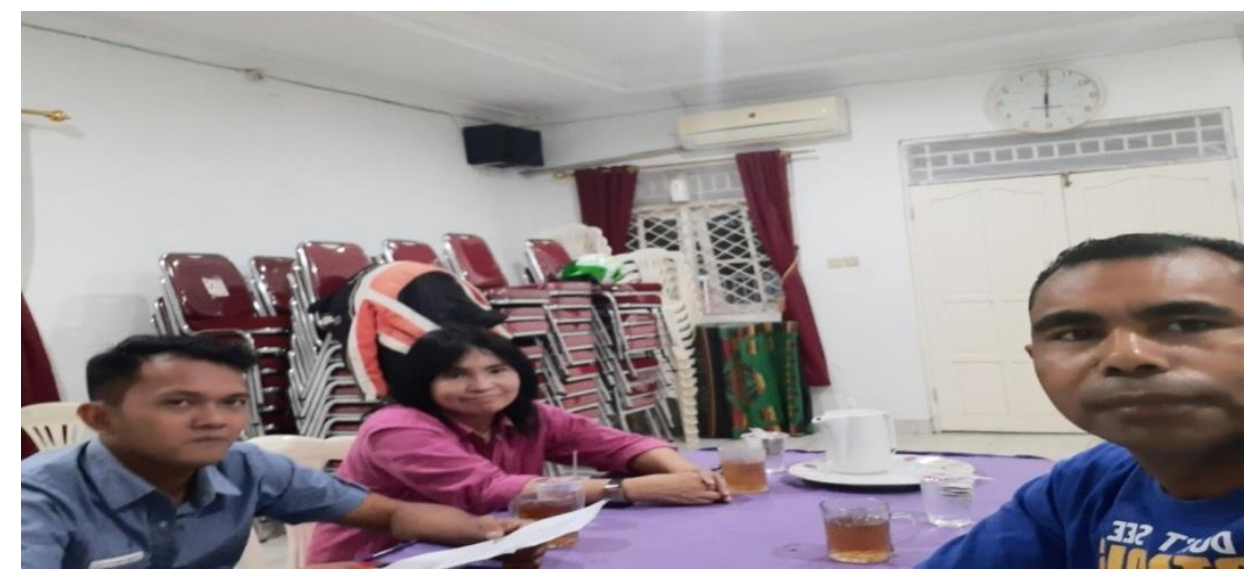




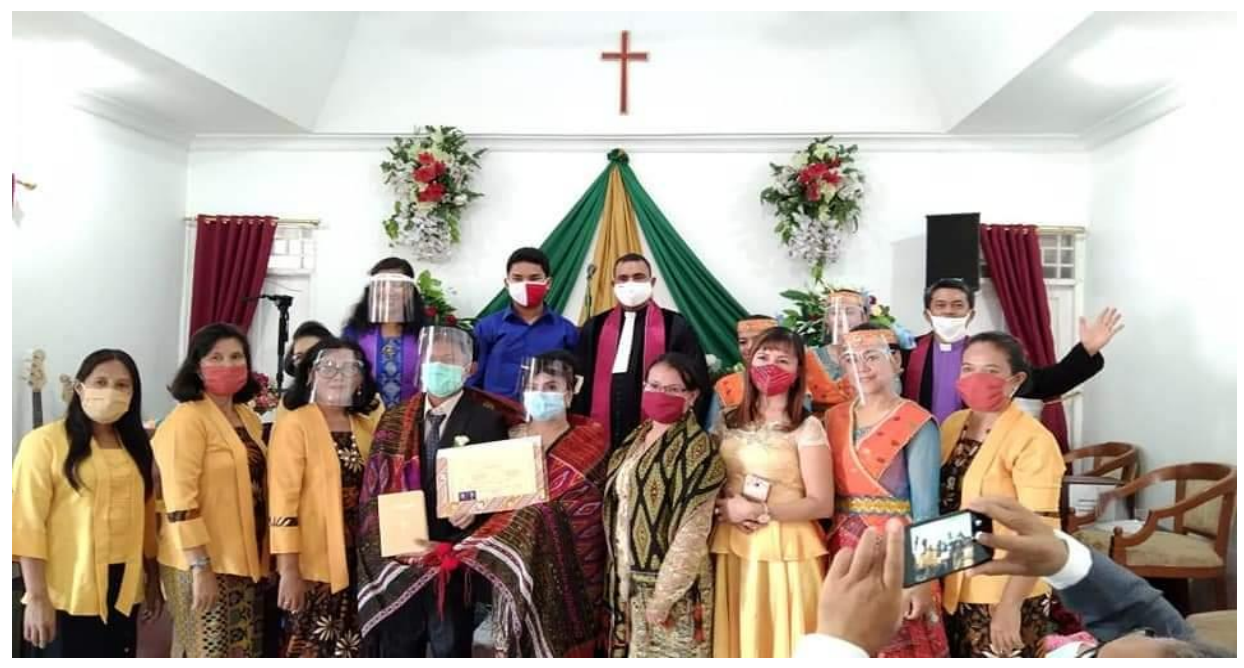

2. Mengikuti konseling pranikah dan kemudian menerima pemberkatan perkawinan kudus pada tanggal 15 Desember 2020
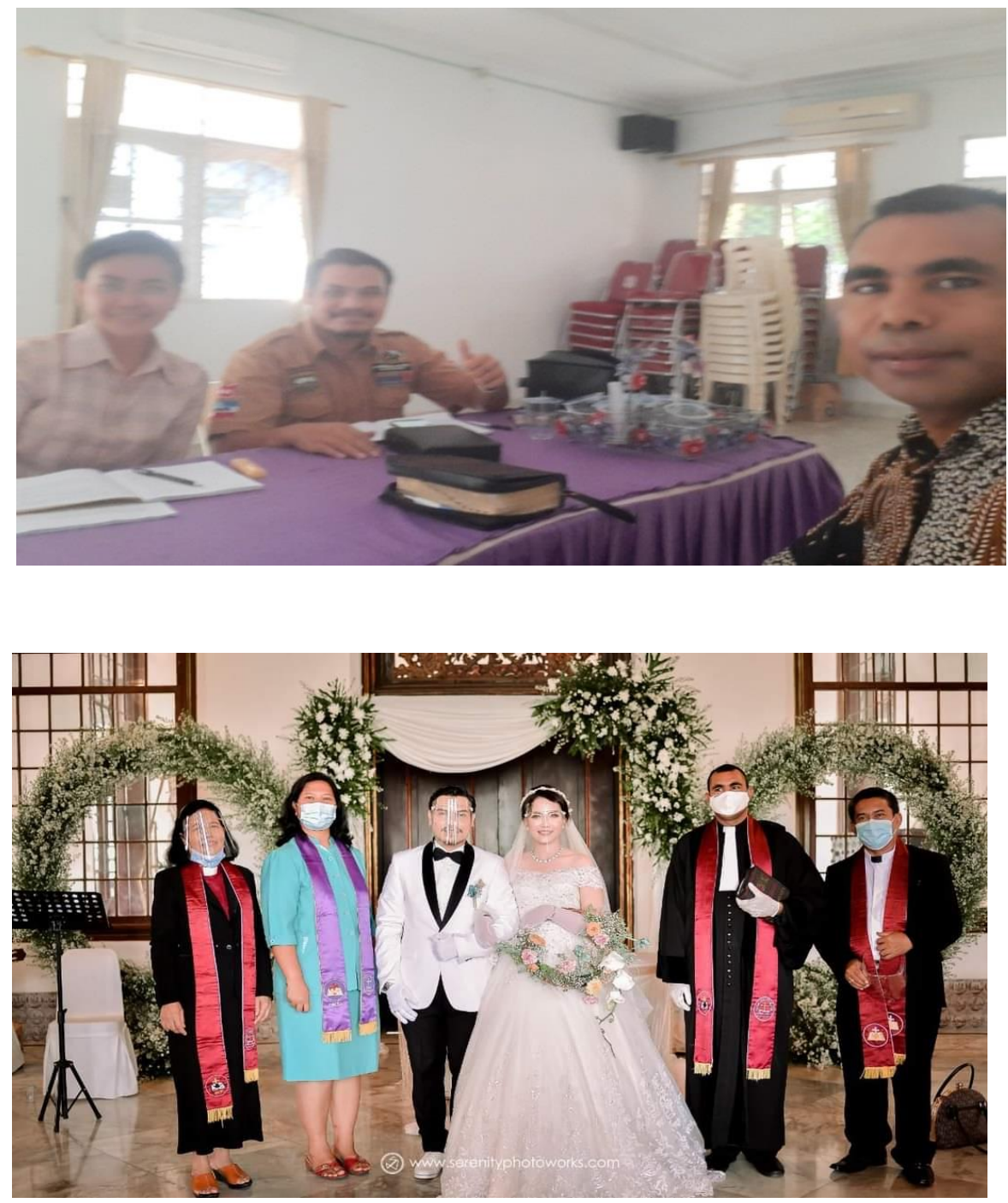


\section{KESIMPULAN}

Berdasarkan hasil penelitian yang telah dibahas di atas, berikut ini beberapa kesimpulan antara lain: pertama, Konseling pranikah sebagai alat dalam mempersiapkan perkawinan seumur hidup sehingga diharapkan semua pasangan yang akan masuk dalam rumah tangga Kristen dapat mengikuti agar setiap pasangan mempersiapkan diri dengan baik. Kedua, Konseling pranikah berguna untuk menyadarkan setiap pasangan agar tahu tentang siapa dirinya, apa yang menjadi kelemahan yang perlu diketahui dan memiliki strategi untuk membuang sehingga tidak membawa masuk dalam rumah tangga Kristen yang berdampak merusak rumah tangga Kristen. Ketiga, Perlunya gereja memberikan pengertian kepada jemaat tentang betapa pentingnya konseling pranikah agar setiap pasangan yang mau masuk dalam rumah tangga Kristen dapat mengikuti proses konseling pranikah dengan baik. Kelima, Gereja perlu mewajibkan setiap pasangan yang masuk dalam rumah tangga Kristen mengikuti konseling pranikah.

\section{DAFTAR PUSTAKA}

Armand Barus. Spiritualitas Pastoral. Jakarta: Sekolah Tinggi Teologi Amanat Agung, 2019.

Hines, Darrell L. Pernikahan Kristen - Konflik \& Solusinya. Diedit oleh Rika Uli Napitupulu - Simorangkir. Jakarta: BPK. Gunung Mulia, 2018.

Illu, Jonidius. "Peran Gereja Dalam Pelayanan Pastoral Terhadap Pasangan Hamil Sebelum Menikah." Phronesis 3 No. 1 Ju (2020).

King, Clayton \& Charie. 12 Pertanyaan yang harus diajukan Sebelum Anda Menikah. Jakarta: Immanuel, 2013.

Lumintang, Stevri Indra Lumintang \& Danik Astuti. Theologi Pernikahan Kristen di Tengah Krisis. Jakarta: Ithl, 2016.

Manalu, Evi Oktavia. Pengaruh Konseling Pranikah Terhadap Keutuhan Keluarga. Jurnal Teologi dan Pelayanan. Vol. 6, 2020. https://sttintheos.ac.id/ejournal/index.php/antusias.

Mathis, Dale Mathis \& Susan. Menuju Pernikahan yang Sehat dan Solid. Yogyakarta: ANDI, 2014.

Powlison, David. Mengatakan Kebenaran Dalam Kasih. Surabaya: Momentum, 2011.

Ridderbos, Herman. Paulus Pemikiran Utama Theologinya. Diedit oleh Steve Hendra.

Surabaya: Momentum, 2015.

Susabda, Yakub B. Konseling Pastoral. Jakarta: BPK Gunung Mulia, 2014.

-_- Konseling Pranikah. Bandung: Mitra Pustaka, 2005.

-_- Menjadi Konselor Yang Profesional. Yogyakarta: ANDI, 2011.

Trisna, Jonathan A. Two Become One - Membangun dan Mewujudkan Pernikahan Bahagia Sesuai Prinsip Alkitab. Edisi ke-5. Yogyakarta: ANDI, 2017.

Yakub B. Susabda. Pembinaan Keluarga Kristen. Bandung: Mitra Pustaka dan Pionir Jaya, 2011. 